\title{
Jubileusz Profesora Romualda Turkowskiego Warszawa 23 czerwca 2017 r.
}

\section{Laudacja wygłoszona przez Profesora Stefana Józefa Pastuszkę}

Wielce Szacowni Dostojni Goście! Uczestnicy ważnego wydarzenia, odbywającego się w jednym z najpiękniejszych miejsc serca Polski - Warszawy! Szczególnego znaczenia, wręcz symbolicznego, nadaje mu królująca w tej sali kopia pomnika Wincentego Witosa, wybitnego męża stanu, trzykrotnego premiera RP, wybitnego przewódcy ruchu ludowego, któremu Profesor Romuald Turkowski poświęcił wiele cennych publikacji.

Zgromadziła nas wyjątkowa uroczystość - jubileusz 65. rocznicy urodzin i 40-lecia pracy naukowej Profesora dra hab. Romualda Wacława Turkowskiego. Łączy ona w sobie bowiem jak tryptyk: Przeszłość, Teraźniejszość i Przyszłość. Przeszłość Profesora jest bardzo bogata. Przybliżę ją nieco Państwu. Teraźniejszość - to dzisiejsze spotkanie, które wspólnie przeżywamy - już przechodzi do historii. A Przyszłość jest nieodgadniona. Można domniemywać, że uczniowie Profesora różnych etapów edukacji - studenci, magistrowie, doktorzy będą wcielać w życie przynajmniej niektóre idee krzewione przez Profesora. Mam na uwadze przede wszystkim: poszukiwanie prawdy, patriotyzm, demokratyzm, szacunek do bliźniego, postawę tolerancji, szacunek do państwa i narodu.

Sądzę, że wyśmienicie ocenił naszego bohatera Witek Graboś, były wiceprzewodniczący Krajowej Rady Radiofonii i Telewizji, który Go poznał w czasie pracy w tej instytucji. Oto ta ocena:

„Profesor Turkowski to człowiek szlachetny, życzliwy i mądry. (...) W dodatku jest irytująco skromny, nie mając ku temu najmniejszych powodów! To sprawia, że jest osobą wyjątkową. A że ze świecą trzeba szukać ludzi tego formatu intelektualnego i etycznego, życzę Mu, żeby wytrwał w swej odmienności, a sobie - i zapewne wszystkim innym - wiele przyjemności z możliwości przebywania z kimś o takiej wiedzy, osobowości i charakterze. To wielki prezent, który daje nam Profesor nie tylko z okazji jubileuszu, ale także na co dzień”.

Spróbuję odpowiedzieć na pytanie: jakie czynniki miały decydujący wpływ na ukształtowanie Jego osobowości? Niewątpliwie ogromna zasługa w tym jego Rodziców, którzy wyposażyli go w dobre geny i poświęcili swe serca jego wychowaniu. Jego charakter rzeźbili nauczyciele Szkoły Podstawowej w Srebrnej, w której się urodziły, profesorowie Liceum Ogólnokształcącego im. Henryka Sienkiewicza w Płońsku. Szczególne zasługi na tym polu mieli nauczyciele: Mieczysław Antosiewicz uczący historii, prof. Wanda Śnieżyńska - były żołnierz 
Armii Krajowej, uczestniczka powstania warszawskiego, nauczycielka języka polskiego oraz prof. Milica Etinger „Madame” - wychowawczyni klasy i znakomita nauczycielka języka francuskiego i kultury francuskiej.

Dusza historyka Profesora ukształtowała się w czasie studiów w Instytucie Historycznym UW. Szczególną rolę odegrało tu uczestnictwo w seminariach wybitnych uczonych prof. Józefa Ryszarda Szaflika, który został jego mistrzem, i prof. Mariana Wojciechowskiego. Udział w seminarium doktorskim profesora Szaflika ukierunkował pasję badawczą naszego Bohatera na dzieje wsi, ruchu ludowego i młodowiejskiego. Później uległa ona znacznemu rozszerzeniu. Objęła parlamentaryzm, oświatę, Wojsko Polskie po II wojnie światowej, dzieje Polonii angielskiej, ruch ludowy w Europie Środkowej, Bataliony Chłopskie, dzieje lokalnych społeczności. Profesor umiejętnie łączył badania regionalne z ogólnopolskimi i europejskimi. Wychodził bowiem z założenia, że w historii lokalnej jak w soczewce odbija się wiele symptomów zjawisk i procesów regionalnych i ogólnokrajowych. Przedmiotem jego zainteresowań były dzieje małych ojczyzn. Przekonany bowiem był i jest, że badania te umożliwiają dyskontowanie dziedzictwa i dorobku lokalnych społeczności w procesie edukacji i patriotycznego wychowania oraz poznania i zrozumienia mechanizmów życia społecznego, kulturalnego, gospodarczego i politycznego oraz roli jednostek w historii. Człowiek musi mieć poczucie zakorzenienia w przeszłości, jeśli chce być w pełni podmiotem, nie przedmiotem toczących się procesów społecznych i politycznych. Ma to szczególne znaczenie dzisiaj, w okresie obrony zagrożonej polskiej demokracji.

Efektem jej są publikacje poświęcone dziejom miast i oświaty, m.in.: Garwolina, Łukowa, rodzinnego Płońska, Białej Podlaskiej, Siedlec, Milanówka, Ostrowca Świętokrzyskiego, Sienna, Łopuszna oraz „Pokusowe Ziarno”, wydane przez Fundację im. Zofii i Władysława Pokusów Wspierania Edukacji Młodzieży Wiejskiej, która powstała dzięki zaangażowaniu wybitnego menadżera polskiego przemysłu i działacza społecznego inż. Stefana Rachwalskiego z Krakowa. Książka ta jest poświęcona owocnej działalności tej fundacji.

Ubocznym, ale ważnym efektem badań Profesora nad dziejami Polonii było przygotowanie w 2000 r. wspólnie ze Stefanem J. Pastuszką wystawy w Wyższej Szkole Menadżerskiej w Legnicy pt.: Prezydenci RP na uchodźstwie a suwerenność Polski, w otwarciu której uczestniczył Prezydent Ryszard Kaczorowski. Wystawa ta cieszyła się dużym powodzeniem. Prezentowana była w różnych miastach Polski. Jej trwałym materialnym i duchowym dorobkiem był 162-stronicowy katalog w postaci albumu pod powyższym tytułem.

Od kilku lat prowadzi Profesor kwerendę w archiwach krajowych, państwowych, partyjnych i prywatnych dotyczącą działalności Zjednoczonego Stronnictwa Ludowego w latach 1949-1989. Marzy mu się bowiem synteza ruchu ludowego, tak potrzebna do lepszego poznania życia Polaków w dobie dominacji sowieckiej w Polsce. Prowadzi też badania na temat agraryzmu środkowoeuropejskiego i północnoeuropejskiego w pierwszej połowie XX wieku.

Z wiedzy i doświadczenia Profesora korzystały redakcje czasopism naukowych, uczelnie, instytucje i różne organizacje. W latach 1995-2010 był kierow- 
nikiem Działu Historycznego, członkiem Redakcji „Przeglądu Humanistycznego” i Kolegium Redakcyjnego „Roczników Dziejów Ruchu Ludowego”. Z doświadczenia i wiedzy Profesora Turkowskiego korzystały inne uczelnie, m.in.: Wojskowa Akademia Techniczna w latach 1991-2003 w Katedrze Historii Wojskowości Polskiej, gdzie został zaproszony przez prof. Jerzego Skowronka, Wszechnica Świętokrzyska, Akademia Humanistyczna w Pułtusku, Wyższa Szkoła Menedżerska w Legnicy, Instytut Kształcenia Nauczycieli i Badań Oświatowych Oddział w Kielcach. Związki Profesora z ziemią świętokrzyską, pogłębione emocjami rodzinnymi, zaowocowały także licznymi cennymi publikacjami o ruchu ludowym na tym terenie, szkolnictwie ogólnokształcącym, o dziejach miasteczka Sienno i wieloma innymi wydawanymi w Kielcach, Pińczowie, Ostrowcu Świętokrzyskim.

Profesor pogłębiał swą wiedzę i doświadczenia dydaktyczne w ramach międzynarodowej wymiany dydaktycznej. Wielokrotnie przebywał w University of London, London School of Slavonic and East European Studies, Uniwersytecie Karola w Pradze, Uniwersytecie w Bratysławie im. Amosa Komeńskiego, Uniwersytecie Polskim na Obczyźnie i Instytucie Polskim i Muzeum im. gen. Władysława Sikorskiego w Londynie. W Instytucie Polskim i Muzeum w Londynie miał odczyty naukowe licznie odwiedzane przez polskich emigrantów dotyczące dziejów polskiej emigracji politycznej. Romuald Turkowski był kilkukrotnie stypendystą Polonia Aid Foundation Trust w Londynie.

Dorobek naukowy R. Turkowskiego to ponad dwieście publikacji, w tym 15 książek monograficznych oraz 15 tomów wydawnictw źródłowych, ponad 180 artykułów, recenzji, doniesień naukowych, itp. Publikacje są zróżnicowane tematycznie. Tytułem egzemplifikacji wymieniam niektóre z nich: Polskie Stronnictwo Ludowe w obronie demokracji 1945-1949, Parlamentaryzm polski na uchodźstwie 1945-1972, dwutomowe dzieło Agraryści czechosłowaccy w latach 1989-1989, dwie części Dziejów Sienna. Godny przypomnienia jest kilkutomowy wybór dokumentów przygotowany wspólnie z profesorami: J.R. Szaflikiem, Adamem Koseskim, Bronisławem Szwarcem, wydany przez Akademię Humanistyczna w Pułtusku.

Droga naukowa i awanse Profesora Turkowskiego, chociaż pochodzi ze wsi Srebrna, nie była „srebrna-sielska”, usłana różami, lecz pełna trudów i barier o charakterze społecznym i kulturowym. Studiował w latach 1969-1974, a więc w okresie, kiedy jeszcze występowały uprzedzenia, a niekiedy wręcz niechęć środowisk wielkomiejskich różnego autoramentu do młodego pokolenia wsi polskiej dążącego do nobilitacji i pełnego uobywatelnienia drogą studiów. Nasz Jubilat rozbroił wątpiących swoim twórczym uporem, benedyktyńską pracą, solidnością i szlachetną postawą. Oczywistym wyrazem były jego awanse naukowe i w strukturach Instytutu Historycznego UW. W 1981 r. obronił rozprawę doktorską poświęconą Związkowi Samopomocy Chłopskiej i akcji uspółdzielczania wsi na terenie województwa kieleckiego, przygotowana (pod kierunkiem prof. dr hab. J.R. Szaflika), w roku 1992 uzyskał tytuł dra habilitowanego. W 1994 r. został zatrudniony na etacie profesora UW na 5 lat, a w 1999 r. zatrudniono go na czas nieokreślony. W 2003 r. po przejściu całej procedury nominacyjnej R. Turkowski 
otrzymał z rąk prezydenta RP Aleksandra Kwaśniewskiego dyplom o nadaniu mu tytułu naukowego profesora nauk humanistycznych. W 2003 r. został on zatrudniony na etacie prof. nadzwyczajnego.

Godna podkreślenia jest współpraca Profesora z organizacjami naukowymi w Polsce, m.in. z Ludowym Towarzystwem Naukowo-Kulturalnym, którego jest członkiem władz. Jest także aktywnym członkiem Towarzystwa Przyjaciół Sienna, w którego pracach również aktywnie uczestniczy. Brał udział w kilkuset seminariach i konferencjach naukowych dotyczących uprawianej przez siebie problematyki. W latach 1995-2015 był uczestnikiem pięciu Kongresów Historyków Wsi i Ruchu Ludowego, których inicjatorem był profesor J.R. Szaflik. Był wiceprzewodniczącym II Kongresu Historyków Wsi i Ruchu Ludowego w Lublinie oraz współorganizatorem III Kongresu w 2006 r. w Pułtusku. Wyrazem uznania dla wkładu Profesora w badania życia Polonii było zaproszenie go do wygłoszenia referatu na III Kongresie Kultury Polskiej na Obczyźnie, który odbył się w sierpniu 1995 r. w Londynie.

Ważnym etapem w życiu naukowym Profesora były jego przyjacielskie i naukowe kontakty z żołnierzami II Korpusu PSZ, dowodzonego przez gen. Władysława Andersa: Janem Szynalskim - redaktorem „Jutra Polski” i ppłk. dr. Władysławem Szkodą oraz redaktorem Zbigniewem Błażyńskim, kierownikiem Sekcji Polskiej BBC, także Franciszkiem Wilkiem - przewódcą PSL na emigracji po śmierci Stanisława Mikołajczyka.

Profesor z pasją łączył pracę naukową i dydaktyczną z działalnością społeczną i polityczną. Był aktywnym członkiem ZMW, ZSL. Od 1990 r. cenionym członkiem PSL. Za zasługi na tym polu odznaczony został medalami Wincentego Witosa, Macieja Rataja, Złotą Odznaką ZMW.

Wyrazem uznania dla pracy i osiągnięć Profesora są licznej odznaczenia: Złoty Krzyż Zasługi (1987), Krzyż Kawalerski Orderu Odrodzenia Polski (2005); brązowe medale: Za zasługi dla obronności kraju (2010), Za zasługi dla Wojskowej Akademii Technicznej (2002); Honorowa Odznaka Wojskowej Akademii Technicznej (2011), Honorowa Odznaka Związku Żołnierzy Batalionów Chłopskich (2009) - za zasługi dla utrwalania pamięci o czynie BCh i SL Roch w czasie II wojny światowej, Medal Akademii Humanistycznej im. W. Gieysztora w Pułtusku - 1994-2004; w 2009 r. uhonorowany został Medalem im. A. Gieysztora oraz medalem im. Andrzeja Bartnickiego. W lutym 2003 r. Zarząd Główny Ogólnopolskiego Związku Żołnierzy Batalionów Chłopskich uhonorował go za zasługi w dziedzinie utrwalania prawdy i pamięci w historiografii polskiej i świadomości społeczeństwa o wsi walczącej o Polskę wolną i sprawiedliwą w latach 1939-1945. Wyrazem uznania dla dorobku naukowego Profesora i jego autorytetu było powołanie go 27 marca 1997 r. przez Leszka Millera, ministra spraw wewnętrznych RP, w skład Rady do spraw Archiwów Ministerstwa Spraw Wewnętrznych i Administracji. Cennym wyróżnieniem było uhonorowanie 5 grudnia 2015 r. Profesora Turkowskiego medalem pamiątkowym „Pro Masovia” przez Marszałka Województwa Mazowieckiego dra Adama Struzika. W 1993 r. Fundacja im. Macieja Rataja przyznała R. Turkowskiemu nagrodę im. Macieja Rataja 
za książkę Polskie Stronnictwo Ludowe w obronie demokracji 1945-1949. Profesor R. Turkowski położył duże zasługi na polu badania dziejów Miejsc Pamięci Narodowej i Polonii. Docenione zostały one przez władze Uniwersytetu Warszawskiego i Światową Radę Badań nad Polonią, która w czerwcu 2003 r. uhonorowała go dyplomem „Za wybitne osiągnięcia w Badaniach nad Polonią”. W 2001 r. Jury Nagrody „Clio” Wydziału Historycznego Uniwersytetu Warszawskiego przyznało R. Turkowskiemu nagrodę II stopnia za książkę Parlamentaryzm polski na uchodźstwie 1945-1972 w okresie rozbicia emigracji politycznej w Londynie. Rok wcześniej Rektor UW przyznał także nagrodę indywidualną II stopnia za tę cenną publikację. Zapewne dużym przeżyciem dla niego było wręczenie mu 14 grudnia 2014 r. w czasie wigilijnego spotkania Złotego Medalu Opiekuna przez prof. Władysława Bartoszewskiego, Przewodniczącego Rady Ochrony Pamięci Walk i Męczeństwa.

W dniu 9 grudnia 2016 roku profesor otrzymał Nagrodę im. Henryka Wereszyckiego i Wacława Felczaka przyznawaną przez Krakowski Oddział Polskiego Towarzystwa Historycznego i Wydział Historyczny Uniwersytetu Jagiellońskiego za dwutomową książkę pt. Agraryści czechosłowaccy w latach 1899-1989 wydaną w Warszawie w latach 2012-2013. Jury tej nagrody uznało ją za najciekawszą pracę dotyczącą dziejów narodów Europy Środkowo-Wschodniej w drugiej połowie XIX wieku i w wieku XX, oraz za zauważenie ich relacji z Polską.

Profesor Turkowski ma znaczące osiągniecia na polu kształcenia młodego pokolenia Polaków. Wypromował bowiem 282 magistrów historii, w tym 147 w Instytucie Historycznym UW, a 135 w Akademii Humanistycznej im. Aleksandra Gieysztora w Pułtusku. Pod jego kierunkiem naukowym stopień doktora nauk humanistycznych w zakresie historii uzyskało 8 adeptów historii, w tym 3 w Instytucie Historycznym, a 5 w Akademii Humanistycznej w Pułtusku. Imponujący dorobek Jubilata jest efektem jego wręcz benedyktyńskiej pracowitości i cierpliwości, rozległości zainteresowań badawczych.

Zwieńczeniem życia rodzinnego Profesora i jego oddania dla historii było i jest małżeństwo z Ewą Filippoto, koleżanką ze studiów na UW, potem wieloletnią pracownicą Muzeum Niepodległości - Muzeum X Pawilonu w Warszawie. Jednym z czynników trwałości tego małżeństwa jest trójka dzieci: syn Przemysław (psycholog i biolog) oraz córki Jadwiga (resocjalizatorka) i Kinga (historykafrykanista i archiwistka). Ma on też sporą gromadkę przeuroczych wnuków: Szymona, Karola, Huberta, Wojciecha i Jerzego. Romuald Turkowski jako chłop z pochodzenia nadal jest związany ze swoją ojcowizną, której kawałek posiada w rodzinnej wsi Srebrna, odwiedza, a kiedy potrzeba pracuje na niej.

\section{Stefan Józef Pastuszka}

Wyższa Szkoła Umiejętności Zawodowych w Pińczowie 


\title{
Wystąpienie Jubilata
}

\author{
Szanowni Państwo,
}

bardzo Państwu dziękuję za przybycie na uroczystość moich dwóch rocznic: 65. rocznicy urodzin i 40-lecia pracy naukowo-dydaktycznej. Jestem szczególnie wdzięczny wszystkim Państwu (45 autorom), którzy zechcieli napisać artykuły naukowe do tomu studiów pt.: Państwo-Demokracja-Chłopi. Studia z historii społeczno-politycznej Polski (XVII-XX w.), przygotowanego pod redakcją S.J. Pastuszki i J. Sztejnbis-Zdyb z Uniwersytetu Jana Kochanowskiego w Kielcach, wydanego niedawno drukiem (z opóźnieniem spowodowanym ważnymi wydarzeniami losowymi redaktora i adresata tomu). Szczególnie dziękuję Panom: Dyrektorowi Muzeum Historii Polskiego Ruchu Ludowego dr. Januszowi Gmitrukowi, Rektorowi Akademii Humanistycznej im. A. Gieysztora w Pułtusku prof. Adamowi Koseskiemu, Rektorowi Wszechnicy Świętokrzyskiej w Kielcach prof. Mieczysławowi Adamczykowi, Prezesowi Oddziału Kieleckiego Ludowego Towarzystwa Naukowo-Kulturalnego, redaktorowi Stanisławowi Durlejowi za wsparcie publikacji tego tomu studiów.

Niedługo minie 50 lat jak trafiłem z dniem 1 X 1969 do Instytutu Historycznego Uniwersytetu Warszawskiego po udanie zdanym egzaminie wstępnym. Do dzisiaj w moim archiwum przechowuję zawiadomienie z podpisem profesora Stanisława Herbsta - Dziekana Wydziału Historycznego o tym radosnym dla mnie fakcie. W ten oto sposób, po 4 latach nauki w Liceum Ogólnokształcącym w Płońsku, trafiłem do IH UW, i jak się okazało, pozostałem w nim na niemal całe moje dorosłe życie. Po przebrnięciu pierwszych 2 lat studiów, uporaniu się z historią starożytną u pani prof. Ewy Wipszyckiej-Bravo i pana dr. Jana Trynkowskiego, średniowieczem u panów prof. prof. Benedykta Ziętary, Andrzeja Wyrobisza i Henryka Samsonowicza dotarłem na rok III, gdzie trafiłem (1971 r.) na seminarium do ówczesnego doc. dr hab. Józefa Ryszarda Szaflika - badacza dziejów wsi i ruchu ludowego w drugiej połowie XIX i XX wieku. W ten też sposób rozpoczęła się moja przygoda z poznawaniem dziejów Polski w drugiej połowie XIX i w XX wieku ze szczególnym uwzględnieniem problematyki wiejskiej. Istnienie takiego seminarium na UW i w IH było możliwe dzięki pozycji naukowej zdobytej przez mojego Mistrza i opiekuna naukowego prof. dr. hab. J.R. Szaflika. Niewątpliwym było, że Zakład Historii Ruchu Ludowego kierowany przez niego, a potem już przez innych badaczy, stał się zapleczem naukowym tego nurtu badań. W 1971 r. trafiłem, jak wspomniałem, na seminarium prof. J.R Szaflika, stało się ono moim pierwszym seminarium. Zgodnie z ówczesnym programem uczęszczałem na kilka innych seminariów, m.in.: doc. dr. Andrzeja Garlickiego o II RP, ale i seminarium prof. Jaremy Maciszewskiego o szlachcie polskiej i jej państwie. Podczas seminarium magisterskiego zająłem się dziejami II RP, pisząc o historii Mazowieckiego Związku Młodzieży Wiejskiej RP „Wici” w latach 1928-1939. W 1974 r. napisałem rozprawę magisterską i zdałem przewidziany przepisami egzamin, uzyskując tytuł mgr. historii. Wówczas to, dość niespodziewanie dla mnie, profesor J.R. Szaflik zaproponował mi pracę w Instytucie Historycznym UW 
w charakterze asystenta-stażysty w Zakładzie Historii Najnowszej. We wrześniu 1974 r., wraz z moim Mistrzem, zostaliśmy przyjęci przez dyrektora IH UW prof. dr hab. Aleksandra Gieysztora. Było to dla mnie wydarzenie przełomowe, bo oto ja - mgr specjalizujący się w dziejach wsi i ruchu ludowego - dostałem szansę rozwijania swoich zainteresowań badawczych w najlepszym instytucie historycznym w kraju. Pamiętam treść tej rozmowy oraz wskazówki, których Pan Profesor mi udzielił. Pamiętam, że chodził po pokoju, w tej sytuacji wstaliśmy z prof. J.R. Szaflikiem. Profesor Gieysztor poprosił, abyśmy usiedli, co uczyniliśmy. Wówczas to Pan Profesor (zanotowałem to po wizycie) mówił że: „mimo rożnych napięć międzyludzkich, mimo różnic w poglądach i postawach wobec wydarzeń, których los Polski nam nie szczędzi, mimo różnic w zainteresowaniach i usposobieniach, Instytut tym czym jest nie byłby, gdyby nie swoisty patriotyzm instytutowy jego członków. Pamiętamy kto go nam zaszczepił od pierwszej chwili wznowienia (T. Manteufel). I pamiętamy także, że bez tej afirmacji domu wspólnej sprawy, trudno, byłoby nam pracować dla Alma Mater, dla Kraju, dla Prawdy”. Pan Profesor zachęcał do prowadzenia rzetelnych badań naukowych, szacunku dla odmiennych poglądów politycznych, społecznych, filozoficznych, jako ważnych cech osobowości uczonego. Czytając wiele o życiu i działalności prof. Aleksandra Gieysztora, znalazłem tego typu jego wypowiedzi które kierował także do innych. Jak pamiętam, mój Mistrz - prof. J.R. Szaflik, potwierdził słowa Pana Profesora mówiąc mi, że takiej postawy oczekuje także i on ode mnie. Profesor J.R. Szaflik stwierdził wówczas, że mam szansę rozwijać swoje zainteresowania, acz: „to twardy kawałek chleba, trzeba na niego pracować i po 18 godzin na dobę". Wówczas też stwierdził, że mnie jako młodemu badaczowi pochodzenia chłopskiego, nie mającemu innego oparcia, pozostaje tylko ciężka praca. Może tak pracując, uda się - jak powiedział - coś osiągnąć. To wskazanie prof. J.R. Szaflika towarzyszy mi do dzisiaj. Biorąc do serca wskazówki prof. A. Gieysztora i prof. J.R. Szaflika, po odbyciu rocznej służby wojskowej, postanowiłem wcielić je $\mathrm{w}$ życie. Z tych też powodów, mając czas ustawowy siedmiu lat na doktorat, napisałem i obroniłem go w cztery lata. Stało się to w pamiętnym roku 1981. Pisząc w pracy doktorskiej o uspółdzielczaniu wsi kieleckiej w latach 1944-1956, pamiętałem o wskazówkach obu Profesorów.

W międzyczasie, tj. w latach 1974-1975, odbyłem jednoroczną obowiązkową służbę wojskową w szeregach Wojska Polskiego, gdzie zdobyłem stopień podporucznika rezerwy. W 1975 r. założyłem rodzinę, razem z moją żona Ewą - absolwentką IH UW, uczennicą prof. Stefana Kieniewicza, zbudowaliśmy nasz wspólny dom, pojawiło się troje dzieci. Zawdzięczam mojej żonie Ewie to, że umiejętnie prowadziła sprawy rodzinne, co pozwoliło mi na kontynuowanie mojej pracy naukowej i zawodowej. W $1981 \mathrm{r}$. zostałem zatrudniony na etacie adiunkta. Do połowy lat 80. ubiegłego wieku byłem w ekipie dyrektora Antoniego Mączaka, wicedyrektorów: prof. Jana Kieniewicza, prof. Bronisława Nowaka sekretarzem naukowym IH UW, a także Zastępcą Sekretarza Uniwersyteckiej Komisji Rekrutacyjnej na UW w czasie rektorowania prof. Henryka Samsonowicza. Kierując się ciągle wspomnianymi radami, a także trawestując Winstona Churchilla 
„o pocie i łzach”, kontynuowałem pracę naukową wraz z dydaktyczną. Postanowiłem wyjść z opłotków regionalizmu. Z tych też powodów tematem habilitacji były dramatyczne dzieje Polskiego Stronnictwa Ludowego w latach 1945-1949 pisane u schyłku lat 80 . XX w. W efekcie na przełomie lat 80/90 XX w. zdołałem napisać rozprawę habilitacyjną, zdać kolokwium w 1991 r., opublikować ją już w III RP. W wyniku tych działań otrzymałem stopień dr. hab., otworzyłem seminarium magisterskie, a wraz z profesorem J.R. Szaflikiem również seminarium doktorskie poświęcone dziejom społeczno-politycznym Polski, ze szczególnym uwzględnieniem problematyki wsi i politycznego ruchu chłopskiego a także spraw regionalnych, z czasem Wojska Polskiego i parlamentaryzmu polskiego. Po uzyskaniu habilitacji nie zwalniałem tempa pracy, bo lata 90 . XX i pocz. XXI w. to moje liczne podróże na zachód Europy (Wielkiej Brytanii, Francja, Włochy), a potem i do Europy Środkowej (Czechy, Słowacja, Austria, Węgry) i Południowej (Chorwacja, Słowenia) oraz Północnej (Dania). Zaowocowało to licznym publikacjami o polskim parlamentaryzmie na uchodźstwie $\mathrm{w}$ latach 1939-1991, ruchu agrarnym w Czechosłowacji w latach 1899-1989. W 2003 r. uzyskałem tytułu profesora nauk humanistycznych. Pracowałem też na rzecz IH UW, będąc przez 15 lat w Dyrekcji IH najpierw pod kierunkiem prof. B. Nowaka (1993-2002), a potem prof. Michała Tymowskiego (2002-2008) jako pełnomocnik ds. studiów wieczorowych, potem kierownik ds. tychże studiów, a także podyplomowych i zaocznych. Zgodnie z pragmatyką służbową prowadziłem intensywnie rożnego rodzaju zajęcia w $\mathrm{IH}$, w tym liczne seminaria magisterskie i doktorskie. Zaowocowalo to wypromowaniem ok. 150 magistrów i czterech doktorów. Przez lata pracowałem także w Akademii Humanistycznej w Pułtusku, Wojskowej Akademii Technicznej w Warszawie, we Wszechnicy Świętokrzyskiej w Kielcach, a także organizacjach naukowych - głównie Ludowym Towarzystwie Naukowo-Kulturalnym, Akademickim Towarzystwie Edukacyjno-Naukowym w Pułtusku.

Niewątpliwym jest, że pozycja naukowa która osiągnąłem, możliwa była dlatego, że w IH UW akceptowano ten kierunek badań, wspierano je, czego doświadczyłem i doświadczam do dzisiaj. Spotkałem się również ze wsparciem Muzeum Historii Polskiego Ruchu Ludowego, Akademii Humanistycznej w Pułtusku. Wysoka pozycja IH UW w skali polskiej, utrzymywana od wielu lat przez kolejne ekipy naszego Instytutu, pozwoliła na uzyskanie stypendiów na Uniwersytecie Londyńskim, Polskim Uniwersytecie Na Obczyźnie, Polonia Aid Foundation Trust w Londynie czy nagród, jak ostatnio otrzymana na Uniwersytecie Jagielońskim za publikację o agrarystach czechosłowackich.

Uważam, że poświęcenie się badaniom dziejów Polski, ze szczególnym uwzględnieniem problematyki wsi i ruchu ludowego w XIX do XXI w., było moim obowiązkiem. Wszak przez wieki mój stan chłopski, z którego pochodzę, pozbawiony był elementarnych praw ludzkich i obywatelskich. Prześladowany był i wyzyskiwany przez szlachtę, arystokrację, mieszczaństwo. W czasach współczesnych w XX i XXI w. wieś i chłopi też są nadal niedoceniani. Wielu z nich zatraciło swoją tożsamość polityczną, kulturową, stanową, głosując często na nurty polityczne, które nimi pogardzają. $\mathrm{Z}$ tych też powodów trzeba pisać 
i przypominać o czynach i zasługach dla wsi, dla chłopów, dla ich samodzielnej pozycji w państwie, jaki uczynili dla nich Wincenty Witos, Maciej Rataj, Stanisław Mikołajczyk i wielu innych dzisiaj zapomnianych polityków chłopskich. Będę to czynił póki sił starczy.

\section{Romuald Turkowski}

